\title{
Physicochemical method of fixing mobile sands with local materials
}

\author{
Mauzhuda Muzaffarova*, and Makhamadzhon Mirakhmedov \\ Tashkent State Transport University, Tashkent, Uzbekistan
}

\begin{abstract}
Impregnating composition with water-soluble binders has been elaborated, with the help of which the source of deflation of mobile sands is blocked, and the protective crust obtained on the sandy surface is characterized by resistance to the effects of wind-sand flow, assessed by plastic strength and thickness. The free-flow movement of a binder in a porous body of sand depends mainly on the equivalent diameter of the particles obtained by the joint solution of the internal and external problems of hydrodynamics and the shape factor of the particles. To interpret the experimental results empirically, an indicator of the saturation of the protective crust sand characterizing the impregnation as an unstable process proceeding under the predominant influence of the gravity field with an uneven movement of the liquid front was revealed. The prevalence of the elastic-plastic properties of the protective crust is evidenced by a slight and smooth change in physical and mechanical indicators over time by the third year of operation.
\end{abstract}

\section{Introduction}

The construction and operation of natural and technical systems in sandy deserts, in particular railways and highways, is carried out in difficult physical, geographical and climatic conditions [1]. The difficulty is caused by the negative impact of the wind on the loose sandy surface, causing deflation of loose sand deposits. Subsequently, deflation leads to sand transport and the formation of sand drifts. Sand drifts negatively affect the reliability of natural and technical systems in the context of the safety of movement of ground vehicles. The damage they cause to railways and roads is usually significant. Drifts sharply worsen the technical and operational indicators of roads, lead to premature failure of rails, road pavements, vehicles, and increase their maintenance cost.

Damage from drifts is also inflicted on pipelines, facilities of irrigation and drainage systems, pastures [6]. The onset of moving sands is a real threat that requires a lot of effort to combat. Thus, mitigation of the negative impact of wind is an urgent task for the reliable operation of natural and technical systems in sandy deserts.

There are many engineering mitigation measures (technological solutions) combined into two groups: the consolidation of sands by mechanical barriers and the physicochemical method (FHM) [2-5]. More than 100 known methods of fixing mobile sands are a

\footnotetext{
*Corresponding author: mauguda@mail.ru
} 
significant part of which relates to the physicochemical method. The most radical way among them, in our opinion, is to bring the sand surface to a stationary state.

From the point of view of costs and the possibility of mechanization of work, among the methods of blocking sources of deflation, the most promising is the physicochemical method of creating an artificial material - a protective crust with elastic-viscous properties. The crust is created by impregnating two types of liquid binders: natural multicomponent organic matter (for example, oil) [6,9]; and artificially prepared. The second includes emulsions (for example, bituminous) [7, 8] and water-soluble substances [10, 11]. However, the binders used in these methods in Uzbekistan are absent, and their import is expensive.

\section{Materials and methods}

The main technological method of FMS is the spraying of a binder on a sandy surface [9]. The binder, when sprayed, penetrates into the pores of the sand and moves without pressure into the sandy substrate - it impregnates it by binding the grains of sand together. As a result, a special building material with a specific type of structure is formed - a crust. The crust is a protective coating that prevents deflation (removal and movement) of sands) [1215]. Thus, the binder plays the role of meliorating sand, improving its physical and mechanical properties, ensuring the stability of the resulting protective layer-coating against the abrasive effect of wind-sand flow [6-13]. For this, the protective coating must have specific physical and mechanical properties, in particular, be elastic-plastic [6-8].

The binder should be accessible, technological - capable of being absorbed into the sand after spraying and forming, after penetration into the sand, an elastic-viscous-plastic protective layer that is resistant to the effect of a wind flow saturated with sand carried by it. As a result, deflation stops in the area treated with the ameliorant [16-19, 23]. Moreover, its durability should be as long as possible during at least one growing season. It is important that the binder can form an astringent mass, is non-germicidal, non-toxic, has increased solubility and high stability of an aqueous solution, availability in the purchase and a relatively low price. Therefore, a study was undertaken on the possibility of using dextrin and polyacrylamide glue to create a protective astringent sand crust.

Previously, the authors carried out studies of fixing mobile sands with $2 \%$ dextrin solutions and KP-001 polyacrylamide glue. However, the obtained protective crust based on the above-mentioned binders, despite a certain wind resistance, was fragile and easily destroyed under the influence of concentrated point loads (human legs, livestock hooves). A hypothesis arose to improve the physical and mechanical properties of the protective crust based on a mixture of dextrin and polyacrylamide glue KP-001 and to optimize the working composition of the solution.

It is known that to obtain a stable crust; it is sufficient to provide it with the required elastic-visco-plastic properties, assessed by the express method by aggregated criteria: the thickness of the protective crust $(\mathrm{h} \geq 5 \mathrm{~mm})$ and plastic strength $(\mathrm{Pm} \geq 2.5-2.7 \times 10 \mathrm{MPa})$ [14].

The value of the plastic strength Pm of bindery sand crusts (Table 1) was determined on a conical plastometer of the Moscow State University system.

Under the influence of a combination of atmospheric factors, qualitative changes occur in the structure of the protective coating, which is mainly the result of changes in the properties of the binder. To determine the longevity of the protective material, the aging process was studied. The durability of knitting sand crusts was tested on an IP-1-3 artificial weather apparatus (TU 25-05.1948-75). Testing samples with artificial weather apparatus is based on exposure to UV radiation, temperature, and moisture. The device automatically maintains the temperature, irrigation with distilled water for 3 minutes every 17 minutes, 
continuous irradiation with lamps with an integral heat flux of radiation for electric arc and mercury-quartz lamps $420 \mathrm{~W} / \mathrm{m}^{2}$ with a flux density of the UV part of the spectrum - $60 \pm$ $6 \mathrm{~W} /^{2}$, for xenon lamps the heat flux density is $125 \mathrm{~W} / \mathrm{m}^{2}$ with the UV part of the spectrum density $45 \pm 4.5 \mathrm{~W} / \mathrm{m}^{2}$.

The assessment of changes in the protective coating was made by measuring the plastic strength of the protective coating $\mathrm{P}_{\mathrm{m}}$ and its thickness $\mathrm{h}$ after testing in IP-1-3. For 20, 40, 60 cycles (Figure 2 ) according to the method of Fazylov T.I. [7].

\section{Results and Discussion}

Table 1.Working compositions and physical and mechanical properties of protective coatings obtained with their use.

\begin{tabular}{|c|c|c|c|}
\hline № & Solution composition & Concentration $\mathrm{C}, \%$ & Plastic strength $\mathrm{P}_{m}, \mathrm{~Pa} \times 10^{3}$ \\
\hline \multirow{3}{*}{1} & Dextrin & 1 & \multirow{3}{*}{2.5} \\
\hline & KP-001 glue & 1 & \\
\hline & Water & 98 & \\
\hline \multirow{3}{*}{2} & Dextrin & 1 & \multirow{3}{*}{3} \\
\hline & KP-001 glue & 2 & \\
\hline & Water & 97 & \\
\hline \multirow{3}{*}{3} & Dextrin & 1 & \multirow{3}{*}{4} \\
\hline & KP-001 glue & 3 & \\
\hline & Water & 96 & \\
\hline \multirow{3}{*}{4} & Dextrin & 2 & \multirow{3}{*}{2.5} \\
\hline & KP-001 glue & 1 & \\
\hline & Water & 97 & \\
\hline \multirow{3}{*}{5} & Dextrin & 2 & \multirow{3}{*}{3.5} \\
\hline & KP-001 glue & 2 & \\
\hline & Water & 96 & \\
\hline \multirow{3}{*}{6} & Dextrin & 2 & \multirow{3}{*}{5} \\
\hline & KP-001 glue & 3 & \\
\hline & Water & 95 & \\
\hline \multirow{3}{*}{7} & Dextrin & 3 & \multirow{3}{*}{3} \\
\hline & KP-001 glue & 1 & \\
\hline & Water & 96 & \\
\hline \multirow{3}{*}{8} & Dextrin & 3 & \multirow{3}{*}{4} \\
\hline & KP-001 glue & 2 & \\
\hline & Water & 95 & \\
\hline \multirow{3}{*}{9} & Dextrin & 3 & \multirow{3}{*}{7} \\
\hline & KP-001 glue & 3 & \\
\hline & Water & 94 & \\
\hline
\end{tabular}

The values of the plastic strength of various compositions of solutions satisfy the requirement for the stability of the crust (Table 1). The selected composition with a small margin of plastic strength $\mathrm{P}_{m}=3.5 \times 10^{3} \mathrm{~Pa}$ : dextrin - 2\%, glue KP-001 - 2\%.

The depth of impregnation of the binder in the sand (Fig. 1) was determined using a moisture meter with a probe installed at a depth of up to $100 \mathrm{~mm}$ according to the method proposed by A.I Adylkhodzhaev [8].

A simple comparison of the graphs (Fig. 1) of the dependence of the plastic strength $P_{m}$ and the depth of impregnation $h$ on the consumption of the working composition of the solution dextrin $(2 \%)+\mathrm{KP}-001$ glue $(2 \%)$, the optimal value of the solution consumption is $2-5 l / \mathrm{m}^{2}$, at which the protective crust is resistant. 
By graphic interpretation of the experimental data of the impregnation process, the equations of the dependences of the main technological parameters of protective crusts were obtained, which made it possible to establish the specific costs of the working compositions of binders.

$$
h=2.443 \cdot q-0.13
$$

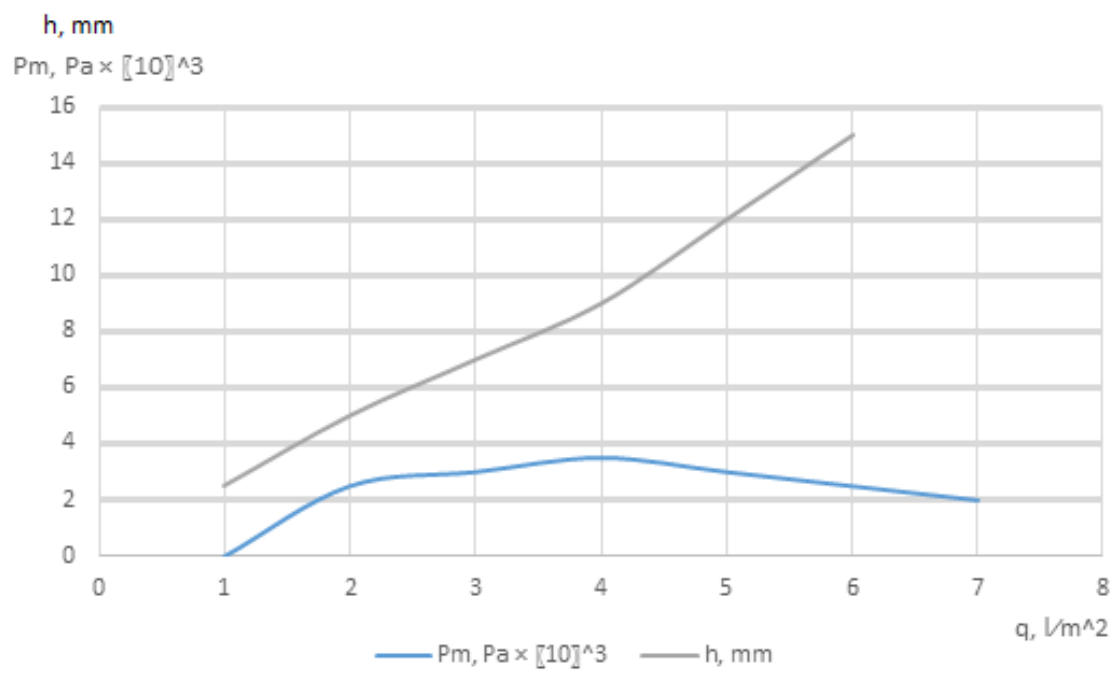

Fig. 1. Dependences of the plastic strength $P_{m}$ and the impregnation depth $\mathrm{h}$ on the consumption of the working composition of the dextrin solution (2\%) and KP-001 glue (2\%).

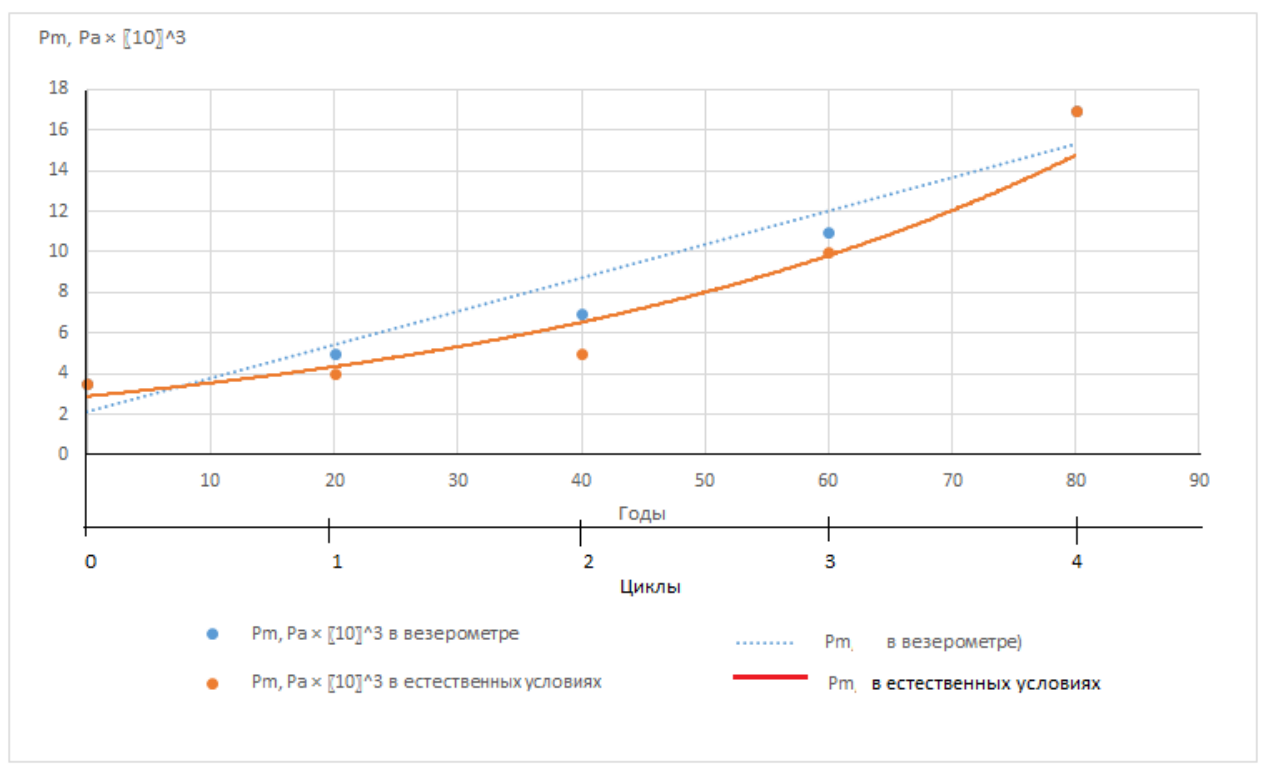

Fig. 2. Study of the durability of protective coatings 
In parallel with the impregnation process, the physical and mechanical parameters of the protective crust were studied. On air dry sand, solutions with various concentrations of binders were impregnated at a specific consumption of $31 / \mathrm{m}^{2}$. On wet sand, the depth of impregnation decreases with an increase in the concentration of the binder (Fig. 9). So, with $1 \%$ solutions, the depth of impregnation reaches $16-17 \mathrm{~mm}, 10 \%$ solution is impregnated to $4-5 \mathrm{~mm}$. It should be noted that at all concentrations, one of the aggregated requirements for wind resistance $(\mathrm{h} \geq 5 \mathrm{~mm})$ is fulfilled with a large margin. Proceeding from this and to save resources, concentrations of more than $5 \%$ were recognized as economically unfeasible; therefore, they were not investigated, and when the second condition of wind resistance $(\mathrm{Pm} \geq 2.5-2.7 \mathrm{MPa})$ is met, the concentration variation limit can be reduced to a minimum (Table 2).

Equation of dependence of plastic strength on specific consumption:

$$
P_{m}=2.31 \cdot \mathrm{q}-0.262 \cdot \mathrm{q}^{2}-1.643
$$

Graphical interpretation of the dependence of the plastic strength $P_{m}$ and the depth of impregnation $h$ on the consumption of the working composition of the solution of dextrin $(2 \%)+\mathrm{KP}-001$ glue $(2 \%)$ revealed the area of variation in the specific consumption of the binder material $2-5 \mathrm{l} / \mathrm{m}^{2}$. For further research, the specific consumption of the binder was adopted, taking into account this limitation of $3 \mathrm{l} / \mathrm{m}^{2}$.

Table 2. Construction and technological characteristics of the protective crust

\begin{tabular}{|c|c|c|c|}
\hline \multirow{2}{*}{$\begin{array}{c}\text { The composition of the solution, } \\
\text { in \% }\end{array}$} & \multicolumn{3}{|c|}{$h(\mathrm{~mm}), P_{m}\left(\mathrm{~Pa} 10^{3}\right), q\left(1 / \mathrm{m}^{2}\right)$} \\
\cline { 2 - 4 } & $h$ & $P_{m}$ & $q$ \\
\hline $\begin{array}{c}\text { Dextrin - } 2, \mathrm{KP}-001 \text { glue - 2, the } \\
\text { rest is water }\end{array}$ & $5-12$ & $3-3,5$ & 3 \\
\hline
\end{tabular}

\subsection{Physical and mechanical properties of the protective crust and characteristics of the new technological solution}

Obtain a stable crust, and it is sufficient to provide it with the required elastic-visco-plastic properties, assessed by aggregated criteria: the thickness of the protective crust $(\mathrm{h} \geq 5 \mathrm{~mm})$ and plastic strength $\left(P_{m} \geq 2,5 \div 2,7 \mathrm{MPa}\right)$ [ 9].

As shown in Table 1, at various ratios of binders and water, a protective coating with admissible plastic strength was obtained. The maximum concentration of each binder is taken no more than $2 \%$ [14]. The technical and economic comparison of the investigated compositions was selected for a composition with a small margin of plastic strength $\mathrm{P}_{m}$ $=3.5 \times 10^{3} \mathrm{~Pa}$ : dextrin $-2 \%$, KP-001 glue $-2 \%$, water $-96 \%$.

The change in structural and mechanical properties is shown in Fig. 2. The figure shows that the plastic strength $\mathrm{P}_{m}$ increases insignificantly by the end of the twentieth cycle. By the end of cycle $40 \mathrm{P}_{m}$ increases by 2.5 times, by the end of 60 - almost 5 times. This indicates that during the impregnation of sand with solutions and impregnation with emulsions [8], with the duration of the tests, plastic deformation turns into elastic.

\subsection{Features of impregnation}

The properties of the protective crust depend on the properties of its components and the peculiarities of their interaction, which are manifested in the process of impregnation of the sandy substrate with a binder, stabilizing the state of the deflated surface. The features of 
gravity impregnation of binders during the fixation of mobile sands of air dry state (3 - 5\%) have been studied in sufficient detail [6], [7-21].

Let us imagine a protective layer in the form of a dispersed system, the phase of which is grains of sand, the medium is a binder. The study of their properties for a deeper disclosure of the mechanism of forming a protective anti-deflation layer seems to be the primary task of the study.

It is known that the physicochemical and technological properties of various compositions based on grain and dispersed materials depend on the number of contacts between particles, which in turn depends on the size, shape and micro relief of particles, and between solid particles and a binder, in addition, depends on the total particle surfaces, the chemical nature of the components and the energy state of the particles. The strength of individual contacts depends on the contact area, the chemical nature of the components and their energy state [6]. Consequently, the ability of the astringent sandy protective crust to perform its function depends entirely on its constituents: sand and binder.

By presenting fluid transfer as a filtration process and solving a mixed problem of hydrodynamics (internal and external), it was possible to determine the internal size of the channel when the sand is impregnated with a binder [14]

$$
d_{k}=\frac{2 \varepsilon}{3(1-\varepsilon)} F d_{e}
$$

Taking from the reference book $\mathrm{F}=0.9$; porosity coefficient $(\varepsilon=0.3-0.45)$ and based on the prevailing fraction of sand in its granulometric composition $(\mathrm{d}=0.14 \mathrm{~mm})$, we can conclude that the equivalent diameter of the channels through which the binder impregnates the air-dry sand, more than $10^{-2} \mathrm{~mm}[9,23]$. Therefore, the impregnation occurs under the predominant influence of the field of gravitational forces.

From the condition of maintaining the volume of liquid before and after impregnation, the volume of the impregnated liquid (Q) should be equal to the pore volume of the substrate in the impregnated layer $Q_{1}\left(Q=Q_{1}\right)$. Having $\left(Q_{1}=Q_{2} \cdot \varepsilon\right)$, where $Q_{2}$ is the volume of sand soaked in liquid, is the volumetric porosity, we get $\left(Q=Q_{2} \cdot \varepsilon\right)$. Assuming equal the area of sand and the area impregnated with a chemical ameliorant $\left(\omega=\omega_{2}\right)$, we obtain $(2)$

$$
\delta=h_{k} / \varepsilon
$$

where, $\delta$ is flow rate, expressed by the initial thickness of the liquid above the sand surface, $\mathrm{mm}$.

Violation of the volume conservation condition, when $\delta \neq h_{k} / \varepsilon$, leads to the introduction of the proportionality coefficient

$$
\delta=h_{k} \frac{k_{n}}{\varepsilon}
$$

where, $k_{n}$ is a proportionality parameter called the coefficient of saturation of the sand with a chemical ameliorant.

Since $\varepsilon_{a}<\varepsilon, \varepsilon_{1}<\varepsilon$ and $\varepsilon=\varepsilon_{1}+\varepsilon_{a}$, then always with free saturation of sand with multicomponent, non-Newtonian fluids, the depth of impregnation will be greater than the theoretically possible value $h>\delta / \varepsilon$. Therefore, the saturation coefficient values less than one are quite plausible $k_{n}<1$, close and more than one $k_{n} \geq 1$, indicate that the saturation limit of sand has come under these conditions and the initial volume of chemical ameliorant $q_{r} \sim \delta$ is not completely saturated. From the technological point of view, the excess of the consumption of the chemical ameliorant $q_{i}>q_{\max }$ more than the maximum 
is not acceptable from the point of view of resource conservation. Those. study of the construction and technological characteristics of the protective layer should be in the range of values $k_{n} \leq 1$ so that $q_{i} \leq q_{\max }$.

When impregnated with solutions, the pore sizes narrow during the impregnation process and, as a result, unstable nature of the movement of the liquid front is observed due to selective adsorption of the dispersed phase of the chemical ameliorant on the hydration layer of the surface of the sand particles, which diffuse from its volume. This phenomenon was confirmed in works [6-14]. As a result, this leads to a decrease in the radius of the smallest passages between the contacting particles, which once again confirms the change in the nature of the transfer from predominantly gravitational to capillary. Thus, we have obtained quite unambiguous evidence of the information content of the saturation coefficient for revealing the nature of the impregnation. Its values, calculated over the entire range of variation of factors, close to the unit $k_{n} \cong 1$, mean that this binder does not separate when penetrating into the sand, the pore space does not narrow, and the process proceeds under the predominant influence of the gravity field. If the values of the saturation coefficient are less than one $\left(k_{n}<1\right)$, and, in the range of variation of the factors, it changes, this means that this binder separates when penetrating into the sand, and the impregnation process proceeds with a narrowing of the pore space under the predominant influence of the field of capillary forces.

It is known that the physicochemical and technological properties of various compositions based on grain and dispersed materials depend on the number of contacts between particles. The number of contacts between solid particles depends entirely on the size, shape and microrelief of the particles and between solid particles and the binder; in addition, it depends on the total surface of the particles, the chemical nature of the components and the energy state of the particles. The strength of individual contacts depends on the contact area, the chemical nature of the components and their energy state. Consequently, the ability of the binder-sand protective crust to perform its function depends entirely on the physicomechanical properties of the sand and the physicochemical properties of the binder.

\section{Conclusions}

1. Impregnating composition has been developed from a combination of water-soluble binders (dextrin and KP-001 glue) to block the source of sand deflation and obtain a protective crust resistant to wind-sand flow.

2. The free-flow movement of the binder in the porous body of sand from the standpoint of the internal and external problems of hydrodynamics made it possible to obtain a formula for the equivalent size of channels taking into account the particle shape factor, which for real desert sands is more than 10-2 mm, i.e. above the limit, the predominance of the field of capillary forces. Thus, the predominance of the gravity field during the impregnation of mobile sand with the recommended composition has been established.

3. A study of the experimental data of impregnation revealed an indicator of saturation of sand with various types of binders, which allows interpreting the nature of the transfer of a binder in air-dry sand as an unstable process proceeding under the predominant influence of the gravity field and leading to an uneven movement of the liquid front; as a result, trapped air bubbles.

4. Studies of the structural and mechanical properties of the protective coating have established a slight gradual increase by the third year of operation, which indicates the predominance of its elastic-plastic properties. In the case of the combined method of fixing mobile sands, namely the physicochemical method combined with phytomelioration, this period is sufficient for the rooting of sand-affectionate plants. 


\section{References}

1. Mirakhmedov M.M. Resursosberegayushchiye organizatsionno-tekhnologicheskiye resheniya bor'by s proyavleniyami ekzogennykh protsessov na zheleznykh dorogakh, p. 424, Tashkent, (2016)

2. Busche, D., Draga, M., Hagdorn, M. Les sables éoliens, modelés et dinamique. La menace éolienne et son contrŏle. Bibliographie annotée/ Deutsche Gesellschaft für technische zusammenarbeit, Schiftereibe. № 1, 122, p. 758, (1984)

3. Mitchell D.J., Fearnehough W, Fullen M.A., Trueman I.C. Wind Erosion and dune stabilisation in Ningxia, China (1996)

4. Khimicheskoye zakrepleniye zasolennykh peskov kok-dar'i arala s pomoshch'yu kompozitsiy-zakrepiteley/ Ekologiya, 12 (30), (1916)

5. Rochette, R.M. Le Sahel en lute contre la désertification; leçonsd'expériences. Weikersheim, Magraf, (1989) p. 592

6. Mirakhmedov M. Osnovy metodologii organizatsii peskozakrepitel'nykh rabot i zashchita prirodno-tekhnicheskikh ob"yektov ot peschanykh zanosov. Monografiya, $p$. 248, TASI, (2008)

7. Fazilov T.I. Organo-mineral'nyye protivodeflyatsionnyye pokrytiya, poluchennyye propitkoy podvizhnykh peskov, Khar'kov, KHISI, p. 44, (1991)

8. Adylkhodzhayev A.I. Primeneniye gossipolovoy emul'sii v kachestve vyazhushchego dlya zakrepleniya podvizhnykh peskov, p. 241, Tashkent, 1978.

9. Yang, Y., Squires, V., Lu, Qi. "Physics, Mechanics and Processes of Dust and Sandstorms" Global Alarm: Dust and Sandstorms from the World's Drylands. United Nations Convention to Combat Desertification. p. 17, (2001)

10. Muzaffarova, M., Mirakhmedov, M., Yuldashov, A. New technological solution for stabilising shifting sand, Proceedins VII International Conference Scientific "Transport problems", Silesian University of Technology, pp. 387-390, Katowice, Poland, (2015)

11. Kuldasheva, SH.A., Adizova, N.Z. Optimizatsiya protsessov khimicheskogo zakrepleniya podvizhnykh pochvogruntov i peskov Arala i Surkhandar'i, 9 (54), (2018)

12. Petrov, M.P. (red.) Obleseniye i zakrepleniye podvizhnykh peskov mira. M: Nauka, p. 389, (1989)

13. Adilkhodjaev A., Hasanov B., Shaumarov S., Kondrashchenko V. Aerated concrete with predetermined pore parameters for the exterior walls of energy efficient buildings, IOP Conference Series: Materials Science and Engineering, 1030(1), 012006, (2021)

14. Khasanov B., Vatin N., Mirzaev T., Suyunov A., Radjabov M. Analysis of the mode of squeezing out excess water for mixing concrete mixture in the process of peristaltic compaction, IOP Conference Series: Materials Science and Engineering, 1030(1), 012021, (2021)

15. Khasanov B., Vatin N., Mirzaev T., Suyunov A., Radjabov M. Physicochemical fundamentals of modifying concrete mix and concrete, IOP Conference Series: Materials Science and Engineering, 1030(1), 012022, (2021)

16. Khasanov B., Vatin N., Ismailova Z., Mirzaev T. Physical modification of concrete mix and concrete, IOP Conference Series: Materials Science and Engineering, 883(1), 012205, (2020) 
17. Khasanov B., Irmuhamedova L., Firlina G., Mirzaev T. Theoretical foundations of the structure formation of cement stone and concrete, IOP Conference Series: Materials Science and Engineering, 2020, 869(3), 032032

18. Mirakhmedov M.M., Muzaffarova M.K. Physicochemical method of fixing shifting sands Mezhdunarodnaya nauchno-tekhnicheskaya konf. «Problemy infrastruktury transportnogo kompleksa, pp.137-138, (2015)

19. Mirakhmedov M., Muzaffarova M.K. New technological decision to fixation movable sands by the physical-chemical method, (2020)

20. Rybakov V., Jos V., Raimova I., and Kudryavtsev K. Modal analysis of frameless arches made of thin-walled steel profiles. IOP Conf. Ser. Mater. Sci. Eng. 883, (2020).

21. Kattakulov F., Muslimov T., Khusainov A., Vokhidov O., Sultanov S. Water resource saving in irrigation networks through improving the efficiency of reinforced concrete coatings, IOP Conference Series: Materials Science and Engineering, 883(1), 012053, (2020) 